\title{
The study of sodium and potassium channel gene single-nucleotide variation significance in non-mechanical forms of epilepsy
}

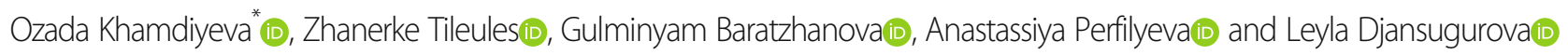

\begin{abstract}
Background: Epilepsy is one of the most common and heterogeneous neurological diseases. The main clinical signs of the disease are repeated symptomatic or idiopathic epileptic seizures of both convulsive and non-convulsive nature that develop against a background of lost or preserved consciousness. The genetic component plays a large role in the etiology of idiopathic forms of epilepsy. The study of the molecular genetic basis of neurological disorders has led to a rapidly growing number of gene mutations known to be involved in hereditary ion channel dysfunction. The aim of this research was to evaluate the involvement of single-nucleotide variants that modify the function of genes (SCN1A, KCNT1, KCNTC1, and KCNQ2) encoding sodium and potassium ion channel polypeptides in the development of epilepsy.
\end{abstract}

Results: De novo mutations in the sodium channel gene SCN1A c.5347G>A (p. Ala1783Thr) were detected in two patients with Dravet syndrome, with a deletion in exon 26 found in one. Three de novo mutations in the potassium channel gene KCNT1 c.2800G>A (p. Ala934Thr), were observed in two patients with temporal lobe epilepsy (TLE) and one patient with residual encephalopathy. Moreover, a control cohort matched to the case cohort did not reveal any SNVs among conditionally healthy individuals, supporting the pathogenic significance of the studied SNVs.

Conclusion: Our results are supported by literature data showing that the sodium ion channel gene SCN1A c.5347G $>$ A mutation may be involved in the pathogenesis of Dravet syndrome. We also note that the c.2800G>A mutation in the potassium channel gene KCNT1 can cause not only autosomal dominant nocturnal frontal lobe epilepsy (ADNFLE) but also other forms of epilepsy. To treat pathogenetic mutations that accelerate the function of sodium and potassium ion channels, we recommend ion channel blockade drug therapy.

Keywords: Epilepsy, Mutation, De novo, lon channel gene

\section{Background}

Epilepsy is one of the most common serious neurological disorders, affecting 4-10 per 1000 people and approximately 50 million people worldwide [1]. Epilepsy comprises a group of chronic brain diseases characterized by chronic recurrent unprovoked seizures caused by abnormal excessive electrical discharges of brain neurons [2]. Epilepsy can be induced by both mechanical

\footnotetext{
* Correspondence: azadahamdieva@gmail.com

Institute of General Genetics and Cytology CS MES RK, Almaty, Kazakhstan
}

and non-mechanical factors. Approximately $20-30 \%$ of epilepsy cases are caused by acquired conditions such as stroke, swelling, or head trauma. Non-mechanical epilepsy forms are associated with hereditary predisposition. Recent data indicate a genetic background in $70-80 \%$ of epilepsy cases [3, 4]. Moreover, some hereditary syndromes (Rett, Dravet, Angelman, West, Prader-Willi, and others) are accompanied by epileptic seizures.

Molecular genetic studies of neurological disorders have led to a rapidly growing number of gene mutations known to be involved in hereditary ion channel
Springer Open
(C) The Author(s). 2021 Open Access This article is licensed under a Creative Commons Attribution 4.0 International License, which permits use, sharing, adaptation, distribution and reproduction in any medium or format, as long as you give appropriate credit to the original author(s) and the source, provide a link to the Creative Commons licence, and indicate if changes were made. The images or other third party material in this article are included in the article's Creative Commons licence, unless indicated otherwise in a credit line to the material. If material is not included in the article's Creative Commons licence and your intended use is not permitted by statutory regulation or exceeds the permitted use, you will need to obtain permission directly from the copyright holder. To view a copy of this licence, visit http://creativecommons.org/licenses/by/4.0/. 
dysfunction (genetic channelopathies). The normal functioning of ion channels is especially important in the nervous system for the generation, repression and distribution of action potentials [5, 6]. Taking into account their importance in neuronal excitability and synaptic transmission through the central and peripheral nervous systems, it is not surprising that mutation of the genes responsible for ion channel functioning can cause epilepsy. Most hereditary epilepsy forms with detected gene mutations are caused by changes to ion channels that ensure neuronal membrane polarization. They include genes encoding sodium, potassium, calcium, and chloride channels (SCN1A, SCN2A, CACNA1A, KCNJ10, KCNT1, KCNC1, KCNQ2, CLCN1) [3, 4, 7-10].

Nonetheless, the list of candidate ion channel genes involved in epilepsy is not restricted by variants in the above genes. Due to large-scale genome-wide studies (GWASs) of epilepsy patients, the spectrum and number of gene mutations possibly involved in epilepsy pathogenesis are increasing every year [11]. However, the low frequency of mutation requires more detailed screening of certain single-nucleotide variants (SNVs) in healthy individuals and in those with different forms of epilepsy.

The aim of this research was to examine involvement in the development of epilepsy single-nucleotide variants that modify the function of genes encoding the polypeptides of sodium and potassium ion channels, as follows: SCN1A (rs121918748, c.5459T>C-p.Phe1820Ser [12], rs571447839, c.5347G>A-p.Ala1783Thr [13], rs121918792, c.5020G >Cp.Gly1674Arg [14], rs121917948, c.4969C>T-p.Pro1657Ala [15]); KCNT1 (rs397515405, c.2782C>T-p.Arg928Cys [16] and rs397515403, c.2800G>A-p.Ala934Thr [17]); KCNC1 (rs727502818, c.959G >A-p.Arg320His [12]); KCNQ2 (rs587777219, c.794C >T-p.Ala265Val [18] and rs28939683, c.851A>G-p.Tyr284Cys [19]).

\section{Methods \\ Sampling}

This "case-control" study was approved by the Local Ethics Committee of Kazakh-Russian Medical University (protocol N.51, 05.09.2017). The studied cohorts included 120 patients with different forms of epilepsy of non-mechanical origin and 120 conditionally healthy individuals. In some cases, the patient's first-degree relatives were included (17 persons). Peripheral blood samples were collected on the basis of the SVS clinic by V.M. Savinov (Almaty, Kazakhstan) and Center of Neurology, Epileptology, and EEG, "Arnur" (Almaty, Kazakhstan). Detailed questionnaires and informed consent were obtained when samples were collected. Epilepsy diagnosis was based on clinical symptoms, electroencephalograms (EEG), and magnetic resonance imaging (MRI) data.

\section{Genotyping of SNVs}

DNA samples were isolated using GeneJet Genomic DNA Purification Kit (Thermo Fisher Scientific, USA) in accordance with the protocol recommended by the manufacturer.

Site-specific PCR amplification with restriction of amplified fragments (PCR-RFLP) was used for genotyping ion channel gene SNVs (rs121918748, rs571447839, rs121918792, rs121917948, rs397515405, rs397515403, rs727502818, rs137989254, rs587777219, rs28939683). Primers were designed by using the PrimerQuest Tool online program. The PCR mixture contained 20-50 ng genomic DNA, $10 \mathrm{pM}$ each specific primer, and $10 \mu \mathrm{L}$ Master mix (2x, Thermo Fisher Scientific, USA). Temperature and time conditions were selected for each SNV by taking into account the size of the primers used (Table 1). Genotyping of SNVs was performed by PCR with subsequent restriction fragment length polymorphism (RFLP) analysis in accordance with the protocol recommended by the manufacturer (Thermo Fisher Scientific, USA).

Restriction endonucleases were selected with the help of WatCut for SNP-RFLP online analysis. The RFLP details are represented in Table 2.

\section{Statistical analysis}

The standard $\mathrm{chi}^{2}$ test was used to assess the significance ( $P$ values) of the observed differences between the case and control groups. An alpha error $(P)$ of less than 0.05 was used as the criterion for significance.

Allele frequencies were calculated in accordance with standard Hardy-Weinberg equilibrium.

\section{Results}

Characteristics of the studied cohorts

Clinical examination of epilepsy patients confirmed the non-mechanical nature of the different epilepsy forms in the individuals in the study cohort. In all patients, neurological status did not show meningeal signs or cerebral symptoms. A memory/attention decrease and emotional liability in the psycho-emotional sphere were detected in one patient. In total, 71 patients had a pathological EEG; 10 individuals had a normal EEG. MRI detected pathologies for 49 individuals, whereas 12 did not have pathological signs. Seizure manifestations allowed us to diagnose the following epilepsy types: temporal epilepsy-10 cases; symptomatic epilepsy-20 cases; residual encephalopathy-14 cases; frontal epilepsy-4 cases; idiopathic epilepsy-18 cases; juvenile myoclonic epilepsy- 6 cases; absence epilepsy- 3 cases; myoclonic epilepsy-case; West syndrome-1 case; Angelman syndrome-2 cases; Dravet syndrome-3 cases; Rett syndrome-1 case; Lennox Gastaut syndrome-1 case. For 
Table 1 The site-specific PCR amplification protocols

\begin{tabular}{|c|c|c|}
\hline Gene, location & SNVs & Primers, $5^{\prime} \rightarrow 3^{\prime}$ \\
\hline \multirow[t]{4}{*}{ SCN1A, 26 exon } & c.5499T>C (p.Phe1820Ser) & \multirow{2}{*}{$\begin{array}{l}\text { f-CCCGACTGTGACCCTAATAAA } \\
\text { r-GTTTGGTTGTGGCAGATTGAG }\end{array}$} \\
\hline & c.5347G>A (p.Ala1783Thr) & \\
\hline & c.5020G>C (p.Gly1674Arg) & $\begin{array}{l}\text { f-GTTTCTTGCCGAGCTGATAGA } \\
\text { r-CGATCCCAACTTCCCTCTTAA }\end{array}$ \\
\hline & c.4969C>T (p.Pro1657Ala) & $\begin{array}{l}\text { f-ACCGGATCCACTGTCTTGATA } \\
\text { r-CGTCTGTAAGCACGCTGAATA }\end{array}$ \\
\hline \multirow[t]{2}{*}{ KCNT1, 24 exon } & c.2782C>T (p.Arg928Cys) & \multirow{2}{*}{$\begin{array}{l}\text { f-CACCCTGAGACCTCCTACAA } \\
\text { r-CCCTITCTCCCACTCTITCTG }\end{array}$} \\
\hline & c.2800G >A (p.Ala934Thr) & \\
\hline \multirow[t]{2}{*}{ KCNQ2, 5 и 6 exon } & c.794 C>T (p.Ala265Val) & $\begin{array}{l}\text { f-TGGTGATGCTTCTGGTGATG } \\
\text { r-GTATCAGCAGGGAAAGGGAAA }\end{array}$ \\
\hline & c.851 A>G (p.Tyr284Cys) & $\begin{array}{l}\text { f-GATCACGCTGACCACCATT } \\
\text { r-GGTCCCACCTAGGGAACT }\end{array}$ \\
\hline KCNC1, 2 exon & c.959 G>A (p.Arg320His) & $\begin{array}{l}\text { f-CTTCGCTTCCCTCTTCTTCAT } \\
\text { r-GAAGATGATGAGCAGCAGGAA }\end{array}$ \\
\hline
\end{tabular}

other patients, the exact type of epilepsy was not determined.

The control cohort representing people without any noticeable neurological pathologies was matched to the case cohort by age, sex, and ethnicity (Table 3 ).

\section{SNV analysis in the control and case cohorts}

The selected ion channel gene SNVs (SCN1A 26 exon c.5459T $>$ C, c.5347G $>$ A, 5020G $>C$, and c. $4969 \mathrm{C}>\mathrm{T}$; KCNT1 24 exon c. $2782 \mathrm{C}>\mathrm{T}$, and c.2800G $>\mathrm{A} ;$ KCNC1 2 exon- c.959G >A; KCNQ2 2 exon c.794C>T, and c.851 $\mathrm{A}>\mathrm{G}$ ) were genotyped in the control and case cohorts.

The studied SNVs were not detected in the control cohort of conditionally healthy persons. Two patients with
Dravet syndrome carried mutations in the sodium channel gene SCN1A. Figure 1 demonstrates the PCR-RFLP results for SCN1A c.5347 G>A (p.Ala1783Thr) mutation screening.

The SCN1A c.5347 G>A (p.Ala1783Thr) mutation was detected in a heterozygous state in an 8-year-old patient. Convulsions first appeared at the age of 3 months and were repeated 2 times a month with different semiotics. Febrile convulsions were not registered. Valproate treatment led only to a slight improvement; treatment was replaced by topiramate, which resulted in a decrease in seizure frequency; worsening of the patient's condition was observed after oxarbazepine treatment. Based on this, treatment with topiramat in combination with valproate and dexamethasone was recommended. However,

Table 2 Restriction endonucleases and SNV specific RFLP details

\begin{tabular}{|c|c|c|c|}
\hline Gene, location & $\begin{array}{l}\text { Mutation/polymorphism//primers } \\
\left(3^{\prime} \rightarrow 5^{\prime}\right)\end{array}$ & $\begin{array}{l}\text { Restriction } \\
\text { endonuclease }\end{array}$ & $\begin{array}{l}\text { DNA fragments length and corresponding } \\
\text { genotype }\end{array}$ \\
\hline \multirow[t]{4}{*}{ SCN1A, 26 exon } & c.5459T>C (p.Phe1820Ser) & Pstl & $\begin{array}{l}\text { ТТ-321 bp; CC-282 и } 39 \text { bp; } \\
\text { ТС-321, } 282 \text { и } 39 \text { bp }\end{array}$ \\
\hline & c.5347G>A (p.Ala1783Thr) & Acc $\|$ & $\begin{array}{l}\text { GG-188 и } 133 \text { bp; AA-321 bp; } \\
\text { GA-321, } 188 \text { и } 133 \text { bp }\end{array}$ \\
\hline & c.5020G>C (p.Gly1674Arg) & Haelll & $\begin{array}{l}\text { GG-90, } 83 \text { и } 75 \text { bp; CC -173 и } 75 \text { bp; } \\
\text { GC-173, 90, } 83 \text { и } 75 \text { bp }\end{array}$ \\
\hline & c.4969C>T (p.Pro1657Ala) & BamHI & $\begin{array}{l}\text { CC-140 и } 108 \text { bp; TТ-248bp; } \\
\text { СТ-248, } 140 \text { и } 108 \text { bp. }\end{array}$ \\
\hline \multirow[t]{2}{*}{ KCNT1, 24 exon } & c.2782C>T (p.Arg928Cys) & HpyF10Vl & $\begin{array}{l}\text { CC-116 и } 117 \text { bp; TТ-233 bp; } \\
\text { СТ-233, } 117 \text { и } 116 \text { bp }\end{array}$ \\
\hline & c.2800G >A (p.Ala934Thr) & Acc $\|$ & $\begin{array}{l}\text { GG-128 и } 105 \text { bp; AA-233 bp; } \\
\text { GA-233, } 128 \text { и } 105 \text { bp }\end{array}$ \\
\hline \multirow[t]{2}{*}{$\begin{array}{l}\text { KCNQ2 } 5 \text { and } 6 \\
\text { exons }\end{array}$} & c.794 C>T (p.Ala265Val) & Rsal & $\begin{array}{l}\text { CC-175 и } 35 \text { bp; ТТ-210 bp; } \\
\text { СТ-210, } 175 \text { и } 35 \text { bp }\end{array}$ \\
\hline & c.851 A>G (p.Tyr284Cys) & Accll & $\begin{array}{l}\text { AA-156 и } 65 \text { bp; GG-221 bp; } \\
\text { AG-221, } 156 \text { и } 65\end{array}$ \\
\hline KCNC1 2 exon & c.959 G>A (p.Arg320His) & $\mathrm{HpyCH} 4 \mathrm{~V}$ & $\begin{array}{l}\text { GG-519 bp, AA-367 и } 152 \text { bp; } \\
\text { GA-519, } 367 \text { и } 152\end{array}$ \\
\hline
\end{tabular}


Table 3 The main characteristics of studied cohorts

\begin{tabular}{|c|c|c|c|c|c|c|}
\hline \multirow{2}{*}{$\begin{array}{l}\text { Cohort } \\
\text { (sample } \\
\text { volume) }\end{array}$} & \multirow{2}{*}{$\begin{array}{l}\text { Years of birth (average } \\
\text { age) }\end{array}$} & \multicolumn{2}{|l|}{ Sex (\%) } & \multicolumn{3}{|c|}{ Ethnicity, persons (\%) } \\
\hline & & Men & Women & Kazakhs & Russian & Other \\
\hline Case(120) & $1960-2017(21.00 \pm 13.00)$ & $74(61.67)$ & $46(38.33)$ & $84(70.00)$ & $23(19.17)$ & $13(10.83)$ \\
\hline Control (120) & $1966-2018(20,72 \pm 11,58)$ & $68(56.67)$ & $52(43.33)$ & $88(73.33)$ & $23(19.17)$ & $9(7.50)$ \\
\hline$t_{\mathrm{st}}$ & 0.01608 & 0.50219 & 0.60277 & 0.30476 & 0 & 0.81371 \\
\hline P & 0.98976 & 0.70371 & 0.65466 & 0.81169 & 1 & 0.56516 \\
\hline
\end{tabular}

despite this, convulsions occurred daily with myoclonia of the eyes and shoulders.

The deletion (33 bp) of exon 26 of the SCN1A gene was detected in another patient, a 4-year-old child (Fig. 2). The first seizures of this patient were marked by twitching of the right hand with gradual involvement of the leg and secondary generalization; at present, attacks begin with tonic tension with subsequent clonic twitches. The EEG for sleeping time demonstrated sharp evoked potentials in the adductions of the left posterior temporal domain and series of bitemporal asynchronous theta waves. As the SCN1A gene deletion was in a heterozygous state, the presence of a second functional copy provides partial SCN1A gene function preservation. Despite the identified mutation, the patient's response to treatment was adequate.

The c.2800G $>$ A (p.Ala934Thr) mutation of the potassium ion channel gene KCNT1 was detected in 3 patients (Fig. 3); two of these patients had temporal lobe epilepsy, and one patient had residual encephalopathy.

Both patients with temporal lobe epilepsy (years of birth 1972 and 1988) had psychomotor automatism attacks with partial seizures. MRI of the patient born in 1972 detected residual subatrophic changes in the brain, and EEG showed a pathological variant that was more indicative of the temporal lobe. The second patient (born in 1988) first experienced attacks at the age of 20. A computer tomography scan of the brain showed that the patient had mild ventriculomegaly of the lateral ventricles, and EEG revealed polymorphic dysrhythmia slightly increased in the temporal-parietal ventricles. The patient was treated with carbamazepine $600 \mathrm{mg} /$ day, but despite this, attacks were occurred every month.

The third carrier of the KCNT1 codon 934 mutation was a patient born in 1987 who had primary generalized tonic-clonic seizures that developed suddenly. MRI revealed congenital peculiarity of mid-brain structure development in the background of non-rough changes in residual genesis.

We performed molecular genetic examinations of the first-degree relatives of patients with detected SNVs to determine the hereditary burden. We did not find SCN1A exon 26 or $K C N T 1$ exon 24 mutations among the close relatives of the indicated patients, supporting the de novo origin of the SCN1A c.5347G>A and KCNT1 c.2800G $>\mathrm{A}$ mutations detected in the children of healthy parents.

\section{Discussion}

In Kazakhstan, more than 70,000 people have epilepsy, of which 28,000 are children, adolescents, and young people; $38 \%$ of patients become disabled, and their

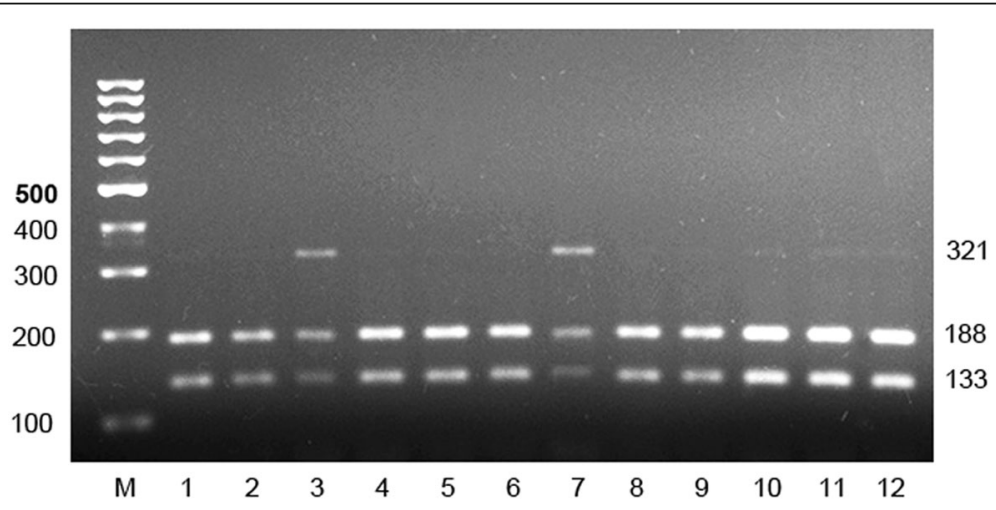

Fig. 1 PCR-RFLP detection of SCN1A gene mutation p.Ala1783Thr (c.5347G>A). M-DNA Ladder GeneRuler 100 bp (Thermo Fisher Scientific, USA); 1,2,5,6,8-11-homozygotes by normal allele c.5347G >A (188 and 133 bp DNA fragments length); 3 and 7-c.5347G>A heterozygote genotype (321, 188 , and 133 bp DNA fragments length) 

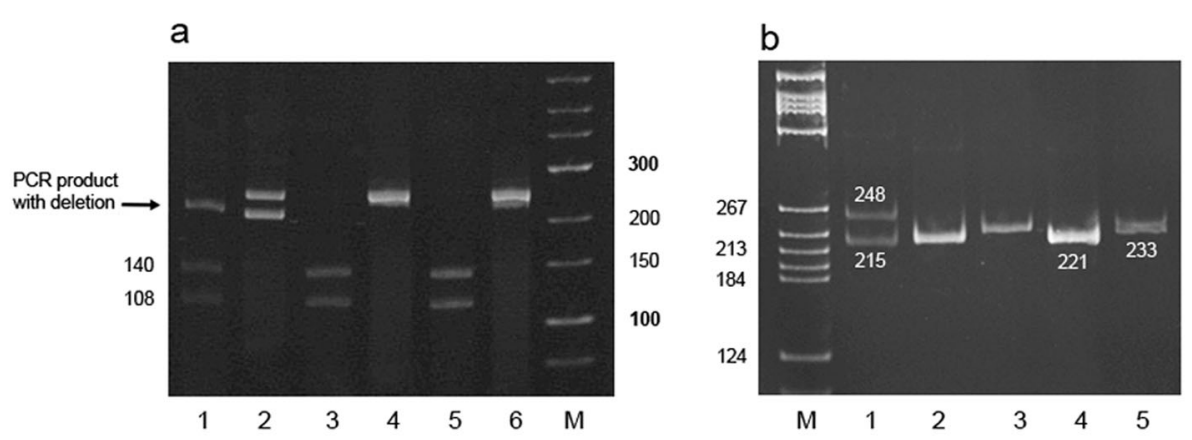

Fig. 2 PCR-RFLP detection of 26 exon SCN1A gene deletion. a M-GeneRuler Low Range DNA Ladder (Thermo Fisher Scientific, USA); 1—the BamHI restriction results of PCR-amplified products of heterozygote with normal and shorted alleles of SCN1A 26 exon: 140 bp and 108 bp DNA fragments, which are the restriction products of normal allele, and the 215 bp DNA shorted DNA fragment; 2 - the 26 exon SCN1A gene PCRamplified products (248 bp and $215 \mathrm{bp}$ ) of patient-carrier of deletion; 3-5-the results of normal PCR-amplified product BamHI restriction: $140 \mathrm{bp}$ and 108 bp DNA fragments; 4-6-the 26 exon SCN1A gene PCR-amplified product (248 bp) of normal sample without mutation; b M-pBR322 DNA/BsuRI (HaellI) Marker; 1-the 26 exon SCN1A gene PCR-amplified products (248 bp and $215 \mathrm{bp}$ ) of patient-carrier of deletion; 2, 4-221 bp DNA fragment used as an additional marker; 3, 5-233 bp DNA fragment used as an additional marker

quality of life decreases by an average of $85 \%$. All patients in this study had generalized idiopathic (27\%), focal (47\%), and epileptic encephalopathies (26\%). The focal seizure type includes symptomatic (76.8\%) and idiopathic forms (23.2\%) [20].

This study regarding the molecular genetic spectrum of epilepsy-associated causative mutations is the first conducted in Kazakhstan. In general, statistical data about epilepsy hereditary form frequency are unavailable, which was the main reason why we chose nonmechanical epilepsy forms, as they can be associated with genetic disorders. The matched control cohort was selected from conditionally healthy individuals after sampling epilepsy cases, taking into account sex, ethnicity, and age.
Worldwide data on the genetics of epilepsy and hereditary syndromes characterized by epileptic seizures are very limited. Basically, data on complete screening of the genomes of patients with various forms of epilepsy are available [21]. As a rule, all identified genetic changes in ethnically heterogeneous populations are single cases or are characterized by a low frequency (less than 1\% of the general population frequency) [22].

Analyzing the available literature sources on the spectrum of genes associated with epilepsy, it is clear that mutations of ion channel genes that alter their function are most often recorded [23-25].

Only a few cases of heterozygous mutations were found in 120 patients with different forms of epilepsy.

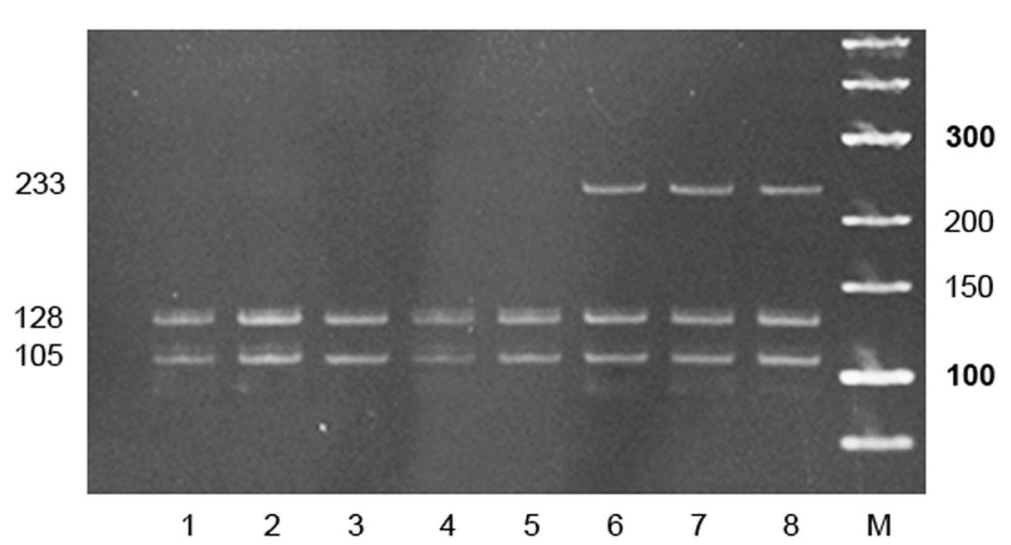

Fig. 3 PCR-RFLP detection of KCNT1 934 codon mutation (c.2800G>A). M-GeneRuler Low Range DNA Ladder (Thermo Fisher Scientific, USA); 1-5-homozygotes by normal allele c.2800G>A (128 and 105 bp DNA fragments length); 6-8-heterozygote genotypes (233, 128, and 105 bp DNA fragments length) 
Moreover, none of the studied SNVs was detected in the control cohort of conditionally healthy persons, though this situation did not allow us to apply the statistical treatment-odds ratio method (OR). Based on the available comparability of case and control cohorts by age, sex, ethnic background, and cohort volume, we consider that the mutations detected (SCN1A c.5347 G>A (p.Ala1783Thr) and KCNT1 c.2800G $>$ A (p.Ala934Thr) have pathogenic significance. In both cases, replacement of a non-polar aliphatic amino acid alanine with a polar oxyaminocarboxylic threonine occurs, which results in a small physicochemical difference of the corresponding polypeptides of sodium and potassium ion channels. Experimental studies have shown that this missense change renders the KCNT1 ion channel constitutively active when assayed in cell culture $[17,26]$. The SCN1A p.Ala1783Thr missense variant was first described in 2007 [27] as being associated with Dravet syndrome, and it is reported as pathogenic in the following databases: (i) HGMD, (ii) Ensembl, and (iii) ClinVar. According to the ACMG criteria, the variant is also classified as pathogenic (PS2, PS3, PM1, PM2, PP2, PP3, PP4, PP5) [28]. This variant is likely to be disruptive, but these predictions have not been confirmed by published functional studies, and their clinical significance is still uncertain. These mutations are proposed to accelerate the functioning of sodium and potassium ion channels [23], causing epileptic seizures.

The frequency of detected SNVs in exon 26 of the sodium channel gene SCN1A (c.5347G>A (p.Ala1783Thr), rs571447839) was 0.01667 , and it was 0.00833 for the 33 $\mathrm{kb}$ deletion. The frequency of SNVs in exon 24 of the potassium ion channel gene KCNT1 (c.2800G>A (p.Ala934Thr), rs397515403) was recorded as 0.025 .

Our results show a more notable frequency for the SNVs rs571447839 and rs39751540 compared to the frequency in global databases (ClinVar, 1000G, Esp6500, ExAC), which can be explained by geographical location or ethnic peculiarities of the studied cohort of epilepsy patients.

Mutations in the SCN1A gene are mostly described for patients with Dravet syndrome, as well as for other epilepsy forms [29-32]. Mutations in the SCN1A gene are inherited autosomal dominantly and lead either to a loss or a change in function. For instance, mutations related to loss of function are more likely associated with Dravet syndrome [33]. However, SCN1A mutations altering sodium ion channel function are mostly recorded for generalized epilepsy with febrile seizures [30]; mutations of this gene are de novo in $95 \%$ of cases [27]. Two studies [13] recorded single de novo cases of $S C N 1 A$ c.5347G $>$ A mutation in patients with Dravet syndrome. Our results are in accordance with these data. Based on a study of first-degree relatives of patients carrying the SCN1A c. $5347 \mathrm{G}>\mathrm{A}$ mutation and $33 \mathrm{~kb}$ deletion, we concluded the de novo occurrence of these mutations in the studied families.

Autosomal dominant mutations in the potassium channel gene KCNT1 are associated with the development of epileptic syndromes such as MMPSI [16, 17, 34, 35], ADNFLE [16], early infantile epileptic encephalopathy (EIEE), and Ohtahara syndrome (OS) [34, 36]. Heterozygous mutations of the KCNT1 gene have been described for patients with infantile epilepsy with migratory focal seizures [17], one patient with leukoencephalopathy, and one patient with severe epilepsy [36].

Ohba $\mathrm{C}$ et al. detected 9 heterozygous mutations in the KCNT1 gene in 11 patients, 10 of which were described as de novo mutations; 1 patient inherited the KCNT1 mutation from a mother with mosaicism [37]. Interestingly, some mutations of the KCNT1 gene (including the KCNT1 c.2800G>A mutation, which was found in our case cohort) are associated with one of two different phenotypes, ADNFLE or MMFSI, even within the same family [38]. This indicates that the relationships of genotype and phenotype for KCNT1 c.2800G >A (p.Ala934Thr) mutation are not unambiguous. Our study shows that the de novo KCNT1 c.2800G>A mutation can occur in patients with temporal lobe epilepsy (TLE) and residual encephalopathy, which indicates the clinical heterogeneity of genetic disorders associated with the KCNT1 gene.

\section{Conclusion}

Our results indicate the possibility of detecting pathological mutations in the SCN1A and KCNT1 genes, even in a small cohort of patients with non-mechanical epilepsy forms, without expensive genome sequencing. Because of high frequency of KCNT1 c.2800G>A (p. Ala934Thr) mutation (0.025) in epilepsy patients from Kazakhstan, we recommend screening for this mutation in patients from the Central Eurasian region with different epilepsy forms, including MMPSI, ADNFLE, EIEE, TLE, and residual encephalopathy. In the future, we plan to use next-generation sequencing (386 genes in the epilepsy panel) to expand the search for new genes and mutations. We hope that this strategy, accompanied primarily by the screening of mutations in other ion channel genes, will help to develop effective therapy protocols for epilepsy patients with non-mechanical forms. We suppose that, in the case of detection of ion channel gene mutations that lead to $\mathrm{Na}, \mathrm{K}$ channelopathies, treatment by agents limiting the distribution of electric potential will be effective. In the case of detecting pathogenetic mutations that accelerate the function of sodium and potassium ion channels, we recommend using therapy based on the effect of ion channel blockade. For example, valproic acid or sodium valproate can block 
sodium ion channels; phenytoin or carbamazepine block sodium and potassium ion channels.

\section{Abbreviations}

SMEl: Severe myoclonic epilepsy of infancy; ADNFLE: Autosomal dominant night frontal lobe epilepsy; MMPSI: Malignant migrating partial seizures of infancy; OS: Ohtahara syndrome; EIEE: Early infantile epileptic

encephalopathy; TLE: Temporal lobe epilepsy; GWASs: Genome-wide studies; SNV: Single-nucleotide variants; EEG: Electroencephalograms; MRI: Magnetic resonance imaging; PCR: Polymerase chain reaction; RFLP: Restriction fragment length polymorphism

\section{Acknowledgements}

We would like to express our gratitude to the professor Sergey V. Savinov, the director of the SVS clinic by V.M. Savinov, (Almaty, Kazakhstan) and doctors for the help in collecting biosamples and clinical testing of patients. We also thank all volunteers of the study.

\section{Authors' contributions}

$\mathrm{DL}$ and OK conceived and designed the study, collected, assembled and interpreted the data, and wrote the manuscript. YE and OA clinically evaluated the patient's interpreted data and wrote the manuscript. ZT, SM, and GB performed the experiments and helped with writing of the manuscript. AP and NK helped critically in revising the manuscript. All authors read and approved the final manuscript.

\section{Funding}

This work was supported by the grant AP05131747 "The study of molecular genetic aspects of hereditary forms of epilepsy in populations from Kazakhstan" received from the Committee of Science, Ministry of Education and Science of Republic of Kazakhstan, 2017-2019.

\section{Availability of data and materials}

The datasets used and/or analyzed during the current study are available from the corresponding author on reasonable request.

\section{Ethics approval and consent to participate}

This study was approved by the Local Ethics Committee of Kazakh-Russian Medical University (protocol N.51, 05.09.2017).

\section{Consent for publication}

Written consent was obtained to participate in this study and to allow us to publish the result of study.

\section{Competing interests}

The authors declare that they have no competing interests.

Received: 22 June 2020 Accepted: 10 December 2020

Published online: 15 January 2021

\section{References}

1. World Health Organization. Epilepsy, key facts. https://www.who.int/newsroom/fact-sheets/detail/epilepsy. Accessed 20 Aug 2020.

2. Chang BS, Lowenstein DH (2003) Epilepsy. N Engl J Med 349:1257-1266 https://www.nejm.org/doi/full/10.1056/NEJMra022308

3. Hildebrand MS, Dahl HH, Damiano JA, Smith RJ, Scheffer IE, Berkovic SF (2013) Recent advances in the molecular genetics of epilepsy. J Med Genet 50:271-279. https://doi.org/10.1136/jmedgenet-2012-101448

4. Wang J, Lin ZJ, Liu L, Xu HQ, Shi YW, Yi YH, He N, Liao WP (2017) Epilepsy-associated genes. Seizure 44:11-20. https://doi.org/10.1016/j. seizure.2016.11.030

5. D'Adamo MC, Liantonio A, Conte E et al (2020) lon channels involvement in neurodevelopmental disorders. Neuroscience 440:337-359. https://doi.org/ 10.1016/j.neuroscience.2020.05.032

6. Smith RS, Walsh CA (2020) Ion channel functions in early brain development. Trends Neurosci 43:103-114. https://doi.org/10.1016/j.tins. 2019.12.004

7. Gan J, Cai Q, Galer P (2019) Mapping the knowledge structure and trends of epilepsy genetics over the past decade A co-word analysis based on medical subject headings terms. Medicine (Baltimore) 98(32):e16782. https:// doi.org/10.1097/MD.0000000000016782
8. Heron SE, Scheffer IE, lona X, Zuberi SM, Birch R, McMahon JM, Bruce CM, Berkovic SF, Mulley JC (2010) De novo SCN1A mutations in Dravet syndrome and related epileptic encephalopathies are largely of paternal origin. J Med Genet 47:137-141. https://doi.org/10.1136/jmg.2008.065912

9. Poryo M, Clasen O, Oehl-Jaschkowitz B, Christmann A, Gortner L, Meyer S (2017) Dravet syndrome: a new causative SCN1A mutation? Clin Case Rep 5(5):613-615. https://doi.org/10.1002/ccr3.787

10. Shi X, Yasumoto S, Nakagawa E, Fukasawa T, Uchiya S, Hirose S (2009) Missense mutation of the sodium channel gene SCN2A causes Dravet syndrome. Brain Dev 31:758-762. https://doi.org/10.1016/j.braindev.2009. 08.009

11. Myers TC, Mefford HC (2015) Advancing epilepsy genetics in the genomic era. Genome Med 7(1):91. https://doi.org/10.1186/s13073-015-0214-7

12. Fujiwara T, Sugawara T, Mazaki-Miyazaki E, Takahashi Y, Fukushima K, Watanabe M, Hara K, Morikawa T, Yagi K, Yamakawa K, Inoue Y (2003) Mutations of sodium channel alpha subunit type 1 (SCN1A) in intractable childhood epilepsies with frequent generalized tonic-clonic seizures. Brain 126(3):531-546. https://doi.org/10.1093/brain/awg053

13. Xu X, Yang X, Wu Q, Liu A, Yang X, Ye AY, Huang AY, Li J, Wang M, Yu Z, Wang S, Zhang Z, Wu X, Wei L (2015) Amplicon resequencing identified parental mosaicism for approximately $10 \%$ of "de novo" SCN1A mutations in children with Dravet syndrome. Hum Mutat 36(9):861-872. https://doi.org/ 10.1002/humu.22819

14. Ohmori I, Ouchida M, Ohtsuka Y, Oka E, Shimizu K (2002) Significant correlation of the SCNIA mutations and severe myoclonic epilepsy in infancy. Biochem Biophys Res Commun 295(1):17-23. https://doi.org/10. 1016/S0006-291X(02)00617-4

15. Mancardi MM, Striano P, Gennaro E et al (2006) Familial occurrence of febrile seizures and epilepsy in severe myoclonic epilepsy of infancy (SMEI) patients with SCN1A mutations. Epilepsia 47(10):1629-1635. https://doi.org/ 10.1111/j.1528-1167.2006.00641.x

16. Heron SE, Smith KR, Bahlo M, Nobili L, Kahana E, Licchetta L, Oliver KL, Mazarib A, Afawi Z, Korczyn A, Plazzi G, Petrou S, Berkovic SF, Scheffer IE, Dibbens LM (2012) Missense mutations in the sodium-gated potassium channel gene KCNT1 cause severe autosomal dominant nocturnal frontal lobe epilepsy. Nat Genet 44(11):1 188-1190. https://doi.org/10.1038/ng.2440

17. Barcia G, Fleming MR, Deligniere A, Gazula VR, Brown MR, Langouet M, Chen H, Kronengold J, Abhyankar A, Cilio R, Nitschke P, Kaminska A, Boddaert N, Casanova JL, Desguerre I, Munnich A, Dulac O, Kaczmarek LK, Colleaux L, Nabbout R (2012) De novo gain-of-function KCNT1 channel mutations cause malignant migrating partial seizures of infancy. Nat Genet 44(11):1255-1259. https://doi.org/10.1038/ng.2441

18. Milh M, Lacoste C, Cacciagli P et al (2015) Variable clinical expression in patients with mosaicism for KCNQ2 mutations. Am J Med Genet A 167A(10): 2314-2318. https://doi.org/10.1002/ajmg.a.37152

19. Castaldo P, del Giudice EM, Coppola G, Pascotto A, Annunziato L, Taglialatela M (2002) Benign familial neonatal convulsions caused by altered gating of KCNQ2/KCNQ3 potassium channels. J Neurosci 22(2):RC199. https://doi.org/10.1523/JNEUROSCI.22-02-j0003.2002

20. Lepesova MM, Kazakenova AK, Tekebaeva LA, Isabekova AA, Myirzalieva BD, Dzhaksyibaeva AH, Dolgopolova GG, Uvasheva NS (2010) The frequency of epilepsy in different regions of the Republic of Kazakhstan. Herald ASIAME 1:10-13

21. Kodera H, Kato M, Nord AS et al (2013) Targeted capture and sequencing for detection of mutations causing early onset epileptic encephalopathy. Epilepsia 54(7):1262-1269

22. Feng YA, Howrigan DP, Abbott LE et al (2019) Ultra-rare genetic variation in the epilepsies: a whole-exome sequencing study of 17,606 individuals. Am J Hum Genet 105(2):267-282. https://doi.org/10.1111/epi.12203

23. Oyrer J, Maljevic S, Scheffer IE, Berkovic SF, Petrou S, Reid CA (2018) lon channels in genetic epilepsy: from genes and mechanisms to diseasetargeted therapies. Pharmacol Rev 70(1):142-173. https://doi.org/10.1124/pr. 117.014456

24. Heyne HO, Baez-Nieto D, lqbal S et al (2020) Predicting functional effects of missense variants in voltage-gated sodium and calcium channels. Sci Transl Med 12(556):eaay6848. https://doi.org/10.1126/scitranslmed.aay6848

25. Nicholas M, Allen MN, Weckhuysen S, Gorman K (2020) Genetic potassium channel-associated epilepsies: clinical review of the Kv family. Eur J Paediatr Neurol 24:105-116. https://doi.org/10.1016/j.ejpn.2019.12.002

26. Milligan JC, Li M, Gazina EV, Heron SE, Nair U, Trager C, Reid CA, Venkat A, Younkin PD, Dlugos JD, Petrovski S, Goldstein BD, Dibbens ML, Scheffer El, 
Berkovic FS, Petrou S (2014) KCNT1 gain of function in 2 epilepsy phenotypes is reversed by quinidine. Ann Neurol 75(4):581-590. https://doi. org/10.1002/ana.24128

27. Harkin LA, McMahon JM, lona X, Dibbens L (2007) The spectrum of SCN1Arelated infantile epileptic encephalopathies. Brain 130(3):843-852. https:// doi.org/10.1093/brain/awm002

28. Richards S, Aziz N, Bale S, Bick D, Das S, Gastier-Foster J, Grody WW, Hegde M, Lyon E, Spector E, Voelkerding K, Rehm LH (2015) Standards and guidelines for the interpretation of sequence variants: a joint consensus recommendation of the American College of Medical Genetics and Genomics and the Association for Molecular Pathology. Genet Med 17(5): 405-424. https://doi.org/10.1038/gim.2015.30

29. Claes L, Del-Favero J, Ceulemans B, Lagae L, Van Broeckhoven C, De Jonghe $P$ (2001) De novo mutations in the sodium-channel gene SCN1A cause severe myoclonic epilepsy of infancy. Am J Hum Genet 68:1327-1332. https://doi.org/10.1086/320609

30. Escayg A, Heils A, MacDonald BT, Haug K, Sander T, Meisler MH (2001) A novel SCNIA mutation associated with generalized epilepsy with febrile seizures plus--and prevalence of variants in patients with epilepsy. Am J Hum Genet 68:866-873. https://doi.org/10.1086/319524

31. Fujiwara T (2006) Clinical spectrum of mutations in SCN1A gene: severe myoclonic epilepsy in infancy and related epilepsies. Epilepsy Res 70(Suppl 1):S223-S230. https://doi.org/10.1016/j.eplepsyres.2006.01.019

32. Gennaro E, Santorelli FM, Bertini E, Buti D, Gaggero R, Gobbi G, Lini M, Granata T, Freri E, Parmeggiani A, Striano P, Veggiotti P, Cardinali S, Bricarelli FD, Minetti C, Zara F (2006) Somatic and germline mosaicisms in severe myoclonic epilepsy of infancy. Biochem Biophys Res Commun 341:489-493. https://doi.org/10.1016/j.bbrc.2005.12.209

33. Zuberi SM, Brunklaus A, Birch R, Reavey E, Duncan J, Forbes GH (2011) Genotype-phenotype associations in SCN1A-related epilepsies. Neurology 76:594-600. https://doi.org/10.1212/WNL.0b013e31820c309b

34. Martin HC, Kim GE, Pagnamenta AT (2014) Clinical whole-genome sequencing in severe early-onset epilepsy reveals new genes and improves molecular diagnosis. Hum Mol Genet 23(12):3200-3211. https://doi.org/10. 1093/hmg/ddu030

35. Ishii A, Shioda M, Okumura A, Kidokoro H, Sakauchi M, Shimada S, Shimizu T, Osawa M, Hirose S, Yamamoto T (2013) A recurrent KCNT1 mutation in two sporadic cases with malignant migrating partial seizures in infancy. Gene 531(2):467-471. https://doi.org/10.1016/.gene.2013.08.096

36. Lim CX, Ricos MG, Dibbens LM, Heron SE (2016) KCNT1 mutations in seizure disorders: the phenotypic spectrum and functional effects. J Med Genet 53(4):217-225. https://doi.org/10.1136/jmedgenet-2015-103508

37. Ohba C, Kato M, Takahashi N et al (2015) De novo KCNT1 mutations in earlyonset epileptic encephalopathy. Epilepsia 56(9):121-128. https://doi.org/10. 1111/epi.13072

38. Moller RS, Heron SE, Larsen LHG (2015) Mutations in KCNT1 cause a spectrum of focal epilepsies. Epilepsia 56(9):114-120. https://doi.org/10. 1111/epi.13071

\section{Publisher's Note}

Springer Nature remains neutral with regard to jurisdictional claims in published maps and institutional affiliations.

\section{Submit your manuscript to a SpringerOpen ${ }^{\circ}$ journal and benefit from:}

- Convenient online submission

- Rigorous peer review

- Open access: articles freely available online

- High visibility within the field

- Retaining the copyright to your article

Submit your next manuscript at $\boldsymbol{\nabla}$ springeropen.com 